\author{
Krešimir Purgar \\ Sveučilište Josipa Jurja Strossmayera u Osijeku, Akademija za umjetnost i kulturu, \\ Ulica kralja Petra Svačića 1/F, HR-31000 Osijek \\ kresimir.purgar@aukos.hr
}

\title{
Što slike znaju?
}

\section{Umjetnost, aproprijacija, kulturalna triangulacija}

\begin{abstract}
Sažetak
U radu nastojimo rasvijetliti postupke koje je potrebno primijeniti utoliko, ukoliko želimo ustanoviti posljedice koje nastupaju kada se sedimenti značenja u slikama talože jedan na drugi stvarajući specifičnu slikovnu epistemologiju. Također ćemo ukazati na neke interdisciplinarne mehanizme analize slikovnog materijala, poput »kulturalne simptomatologije» $i$ »kulturalne triangulacije», a dat ćemo i tipologiju kulturalno-povijesnih sedimentacija slikovnog značenja koje ovdje nazivamo aproprijacija. Zaključit ćemo da Bredekampova teorija slikovnih činova, jednako kao i Mitchellove slike kao »žudeći objekti« te Beltingovo razumijevanje ljudskog tijela kao »medija slike« upućuju na to da je interakcija čovjeka $i$ slike ogledalo njegove vlastite želje za proizvodnjom paralelnog svijeta koji on doživljava stvarnim, ali, kako je to objasnio Lambert Wiesing, ne mora u njemu sudjelovati jer slika omogućava različite oblike participacije ili izostanka iz participacije u stvarnom događaju. Ono što slike »znaju« jest specifična posljedica činjenice da neživi slikovni objekti mogu posjedovati pamćenje, ali - za razliku od umjetne inteligencije - svoje znanje mogu aktivirati samo u recipročnom komunikacijskom odnosu s ljudima.
\end{abstract}

\section{Ključne riječi}

slika, aproprijacija, kulturalna triangulacija, pamćenje slike, W. J. T. Mitchell, Horst Bredekamp, Michele Cometa, David Freedberg

\section{Uvod}

U ljudskoj civilizaciji ne postoji toliko neživih predmeta koje u tolikoj mjeri smatramo živima da im se obraćamo u trenutku patnje ili zbog zadovoljstva i puke distrakcije, stvarajući u nama spokoj ili nezaustavljiv bijes - kao što su to slike. Teško je zamisliti da bi se ljudi tisućama godina mogli obraćati predmetima koje su sami proizveli, poput odjeće, namještaja ili automobila i pritom u njima prepoznavati ono što prepoznaju u slikama; a opet, strogo »tehnički« gledano, slike nisu ni na koji način životnije od bilo kojeg artefakta u dugoj kulturalnoj povijesti čovječanstva. Čak ni tzv. pokrenute ili pokretne slike, poput onih stvorenih tehničkim izumima tijekom 19. stoljeća - phenakistiscope, zoopraxiscope i projiciranje s filmske vrpce $^{1}$ - premda se $^{-}$ doimaju živima, ne sadrže ni one najmanje, nevidljive elemente biološkog života, poput bakterija ili virusa. Ono što slike ipak čini živima jest čovjeko-

O tehničkim i kulturalno-povijesnim aspektima pokretnih slika vidi seminalno djelo Jonathana Craryja Techniques of the Observer, The MIT Press, Massachusetts (MA) 1990., a od novijih, konciznih pregleda odnosa statičnih i pokrenutih slika vidi Mirela Ramljak Purgar,
»Early Interactions of Static and Moving Images«, u; Krešimir Purgar (ur.), The Palgrave Handbook of Image Studies, Palgrave Macmillan, London 2021. 147-166. 
va neutaživa potreba i sposobnost za imaginiranjem onoga što ne postoji te činjenje neprisutnog prisutnim.

U fokusu ovog članka neće biti sami mehanizmi »živih« ili »oživljenih« slika, nego prvenstveno modeli analize koji omogućuju da takve slike bolje razumijemo, a to ćemo učiniti na taj način što se nećemo ograničiti isključivo na one njihove aspekte koji su u središtu interesa pojedinačnih disciplinarnih znanosti. Nastojat ćemo rasvijetliti postupke koje je potrebno primijeniti želimo li ustanoviti posljedice koje nastupaju kada se sedimenti značenja talože jedan na drugi stvarajući specifičnu slikovnu epistemologiju. To je, drugim riječima, naše znanje o slikama, ali i svojevrsno znanje samih slika što ga one prenose u tisućljetnoj interakciji s ljudima. U tekstu ćemo ukazati na neke interdisciplinarne mehanizme analize slikovnog materijala koji ovise o izboru svakoga

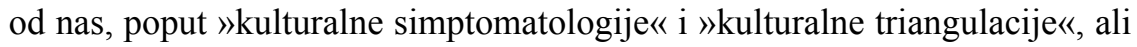
jednako tako skrenut ćemo pozornost i na vrstu kulturalno-povijesnih sedimentacija slikovnoga značenja koje ovdje nazivamo aproprijacija. Da bismo definirali početnu točku našeg istraživanja, krenut ćemo od kratkog prikaza dvaju različitih antropoloških pristupa slikama, Davida Freedberga i Hansa Beltinga; zatim ćemo analizirati okvire slikovne epistemologije kod Michelea Comete i Horsta Bredekampa te naposljetku analizirati mogućnosti kulturalne triangulacije kod Williama Johna Thomasa Mitchella i usporediti je s temeljnim postulatima ikonologije Erwina Panofskog. Naposljetku, predložit ćemo koncept aproprijacije koji, kako držimo, uokviruje singularne metode spomenutih autora usprkos njihovim međusobnim razlikama.

\section{O mogućnosti života slika i života $u$ slikama: Freedberg i Belting}

Slikama su oduvijek pridavane moći koje su nadilazile mogućnosti ljudske spoznaje. Krenemo li od toga da neživi prikazi na kamenim obodima pećina ili tragovi boje na zidovima ranokršćanskih crkava uspijevaju potaknuti ljude na aktivnosti ili vjerovanja koji bi imali posve drugačiji karakter da se nisu na specifičan način nastanili u čovjekovu imaginariju, tada se odgovor na pitanje »što slike znaju?« doima značajnijim od efektne stilske figure. Imaju li slike sposobnost pamćenja i na koji način naslage značenja koje u njih upisujemo ili u njima prepoznajemo utječu na još uvijek zagonetan neksus čovjeka i slike? Naslov ovog teksta nadahnut je naslovom jedne od najpoznatijih knjiga američkog teoretičara vizualnih studija, W. J. T. Mitchella, i premda ovaj autor nije prvi koji je slikama pripisao svojstva živih bića, koja raspolažu vlastitom voljom i u stanju su usmjeravati čovjekove postupke, njegovi su uvidi na izniman način postali dijelom imaginarija suvremene kulture. ${ }^{2}$

$\mathrm{S}$ izvorima u drugačijim teorijama i s različitom metodologijom, prije Mitchella to su učinili David Freedberg, Hans Belting i Alfred Gell. ${ }^{3}$ Međutim, ono što ove autore razlikuje međusobno - a potom i svakog od njih od Mitchella - jest to što su oni usmjereni na ontološko-kulturalnu problematiku slika (Freedberg) i antropološko-kulturalnu problematiku umjetničkih djela (još specifičnije: proto-umjetničkih, što je karakteristično za Beltinga), tj. na recepciju, reakciju ili odgovor promatrača na potpuno različite aspekte doživljavanja i proučavanja slika. Zbog konzistentno korištenih metoda, a koje sam na drugom mjestu nazvao »kulturalna simptomatologija $\ll^{4}-i$ što ću ovdje još proširiti pojmom »kulturalne triangulacije $\ll^{5}$ - svojim razumijevanjem prirode slika Mitchella valja pozicionirati na jednaku distancu od ove trojice. Ova 
usporedba na tragu je uvriježenog mišljenja da se anglo-američka škola vizualne kulture pretežno bavi društvenom uvjetovanošću slika, dok je njemački Bildwissenschaft više zainteresiran za njihov ontološki status, kako je to prvi ustvrdio Keith Moxey. ${ }^{6}$ Naime, dok je Freedberg povjesničar umjetnosti kojeg zanima ontološka problematika slike u povijesnoj perspektivi, Belting je povjesničar umjetnosti koji stalno dovodi u pitanje temeljne postulate vlastite struke; $\mathrm{s}$ druge strane, Mitchellova ekvidistanca prema obje paradigme polazi od posve drugačijih premisa.

Mitchellova intervencija u knjizi iz 2005. godine i eponimno pitanje »What Do Pictures Want?« (»Što slike žele?«) predstavljaju provokaciju upućenu podjednako semiotičkim, kulturološkim i fenomenološkim teorijama slike, a koje su u njima uvijek prepoznavale nežive objekte koji tek univerzalnim označavanjem, identitetskim preferencijama ili intencionalnim činom promatrača u njih udahnjuju život. Slike, naravno, ne mogu biti »žive« bez nas koji ih promatramo, ali mogu biti, najčešće i jesu, »sugovornik « bez kojeg vizualna komunikacija ne bi bila moguća. Mitchellova metafora mišljena je prvenstveno kao stilska figura, dakle, ona sama tek je jedan dio diskurzivnog protokola tumačenja te ne pretpostavlja neku inherentnu hermeneutičku dimenziju slike koja bi u njoj uvijek bila već unaprijed sadržana u vidu slikovne informacije koja provocira određenu reakciju. Za Mitchella, reakcija promatrača na sliku posljedica je specifikuma same slike koja je konstituirana međudjelovanjem

2

O tome vidi u William John Thomas Mitchell, What Do Pictures Want? The Lives and Loves of Images, The University of Chicago Press, Chicago 2005.

3

O tome vidi u Alfred Gell, Art and Agency. An Anthropological Theory, Clarendon Press, Oxford 1998.; David Freedberg, The Power of Images. Studies in the History and Theory of Response, The University of Chicago Press, Chicago 1989.; Hans Belting, Bild und Kult. Eine Geschichte des Bildes vor dem Zeitalter der Kunst, C. H. Beck, München 1990., engl. izd. Hans Belting, Likeness and Presence. A History of the Image before the Era of Art, prev. Edmund Jephcott, The University of Chicago Press, Chicago 1997.

Vidi o tome u: Krešimir Purgar, »Iconology as Cultural Symptomatology: Dinosaurs, Clones and the Golden Calf in Mitchell's Image Theory«, u: Krešimir Purgar (ur.), W. J. T. Mitchell's Image Theory. Living Pictures, Routledge, New York - London 2017., str. 82-99. 5

Pojam triangulacije poznat je iz tzv. »terestričke navigacije «, koja služi za određivanje položaja na moru pomoću triju vidljivih fiksnih točaka na kopnu. U društvenim znanostima, triangulacija polazi od sličnog načela prema kojemu se karakteristike nekog fenomena određuju promatranjem, analizom i predviđanjem razvoja konkretne društvene pojave.

6

Prvu analitičku podjelu na znanstvene »škole« vizualnih studija s jedne i druge strane Atlantika (pojam vizualnih studija ovdje koristimo kao univerzalnu klasifikaciju koja obuhvaća oba glavna teorijska pravca proučavanja slike danas - vizualnu kulturu i znanost o slici), predstavio je Keith Moxey na simpoziju Vizualna konstrukcija kulture u Zagrebu, 2007. godine. Na simpoziju, koji su zajednički organizirali zagrebački Centar za vizualne studije i časopis Tvrđa, Moxey je otvorio put problemskoj artikulaciji teorijsko-metodoloških opreka kulture i ontologije, karakterističnih za glavne škole unutar vizualnih studija. Vidi: Keith Moxey, „Visual Studies and the Iconic Turn«, u: Keith Moxey, Visual Time. The Image in History, Duke University Press, Durham 2013., str. 53-76. Prema tumačenju Žarka Paića, ova opreka ima svoje podrijetlo u razlikama što postoje u tradicijama kritičkog mišljenja između analitičke i kontinentalne filozofije. - Žarko Paić, »German Theory. Bildwissenschaft and the Iconic Turn«, u: K. Purgar (ur.), The Palgrave Handbook of Image Studies str. 703-718. 
fizičke drugotnosti slike kao totema $\mathrm{i}$ idola te istodobno njezinim magičnim učinkom koji se tako duboko utiskuje u čovjeka. ${ }^{7}$

Talijanski teoretičar Luca Vargiu ukazao je na jedan zanemareni problem koji će se pokazati važnim za našu raspravu pri pokušaju odgovora na pitanje »što slike znaju?«. Vargiu skreće pozornost na znanstvenu raspravu između Davida Freedberga i Hansa Beltinga, koja je imala za povod njihove suprotstavljene uvide o prirodi slike za vrijeme Bizanta, tj. različito gledanje na jedan od ključnih događaja u povijesti slika - zaključke Drugoga ekumenskog koncila održanog u Niceji 787. godine. ${ }^{8}$ Da bismo razumjeli meritum rasprave ovih dvaju autora, nužno je podsjetiti da se na nicejskom saboru raspravljalo o karakteru slikovnog prikazivanja, a čiji se ključni aspekt sastojao u dilemi na koji se način slika odnosi prema vlastitom prototipu, tj. onome što je, sukladno uvjerenju ikonofila, reprezentirano, s jedne strane, ili onome što je, sukladno ikonoklastičkoj struji, inkarnirano u slici, s druge strane. Freedberg komentira Beltingovu knjigu Bild und Kult iz 1990., spočitavajući njemačkom autoru nedostatak ontološkog pristupa problematici slike uz posljedičnu predominaciju historijskog diskursa koji tendira tomu da upisuje značenja koja su legitimirana »rigoroznim filološkim analizama«. Jedna je od ključnih Beltingovih teza u toj knjizi da »razdoblje umjetnosti« unutar europske povijesti nastupa tek s Reformacijom, tj. ikonoklastičkim tumačenjem Martina Luthera koji je smatrao da vrijednost slika ne postoji sama po sebi, nego tek $u$ mjeri u kojoj je njihovo značenje uspostavljeno od strane promatrača. ${ }^{9}$

U Freedbergovu osvrtu na Beltingovu knjigu jasan je otpor američkog autora prema »historijskom partikularizmu « potonjega jer Freedberg u svojem nešto ranijem djelu, The Power of Images, inzistira na, kako ih sam naziva, "psihološkim generalizacijama « koje ovise o »univerzalnoj recepciji svih slika«, dakle, bez obzira na to jesu li one svete ili profane. ${ }^{10}$ Nadalje, Freedberg ozbiljno prigovara Beltingu da je previše zaokupljen historijsko-estetičkim osobinama svetih slika i da zato ne uočava problem »inherencije« (koji postoji u svim slikama), a odnosi se na ono o čemu je u Niceji donesen konačan pravorijek - naime, na relaciju između slike božanstva i njezina prototipa, tj. na arbitrarnu međuovisnost reprezentacije i onoga što je pomoću nje simbolizirano. Želimo li to podrobnije objasniti, treba imati na umu da je jedna od odluka nicejskog koncila bila da se slika suštinski razlikuje od prototipa (tj. onoga što reprezentira) i da zato prikazivanje božanstva na slici ne može biti svetogrđe. Marie-José Mondzain navodi jedan pasus iz djela $O$ božanskim slikama bizantskog mislioca Ivana iz Damaska, koji nekoliko desetljeća prije održavanja nicejskog sabora kaže: »Za svaku stvar prvo je ono što je prema prirodi, a tek nakon toga ono što je prema konvenciji [thésin] i prema mimezisu.« Mimezis, stoga, zaključuje Mondzain, u srednjovjekovnoj teologiji nije bliži suštini, već je jednostavna materijalna kopija. Mimezis je ikonički korelat suštine. ${ }^{11}$

Luca Vargiu u svome tekstu apostrofira jedan važan element ove rasprave, koji bismo mogli nazvati transhistorijskim jer su ga i Freedberg i Belting pozicionirali unutar posve spekulativnog područja omeđenog, s jedne strane, srednjevjekovnom teologijom, a s druge, modernim fenomenološkim konceptom intencionalnosti. Vargiu tvrdi da Beltingu nije važno ono što Freedberg naziva »inherencijom « - tj. specifičan sklop prezentacije onoga $n a$ slici i reprezentacije onoga $u$ slici - jer ovaj njemački autor u ontološkoj problematici slikovne reprezentacije ne prepoznaje onaj ključni moment o kojemu se raspravljalo na nicejskom saboru 787. godine. Belting, naime, ne smatra 
da su se srednjovjekovni teolozi bavili slikama na taj način da su najprije uspostavili vlastita »teorijska« uvjerenja, a potom ih nudili kao dogmu, nego da su široko prihvaćena uvjerenja iz svakodnevne kultne prakse a posteriori pretvarali u dogmatske zaključke. Drugim riječima, oni su samo legitimirali ono što su široke mase u slikama intuitivno ili zbog same prirode kršćanskog vjerovanja već unaprijed prepoznavale. Dok se kod Freedberga ontologija i teologija podudaraju ili, bolje rečeno - zahvaljujući »teoriji inherencije« - teolozi pokazuju da im je važan pristup ontološkoj dimenziji slika, za Beltinga teološko objašnjenje proizlazi tek iz naknadnih potvrđivanja značenja koja bi slike imale i bez njih. ${ }^{12}$

\section{Epistemološki okviri analize (umjetničkih) slika: Cometa i Bredekamp}

Za razliku od prethodnih primjera antropomorfizacije slika, talijanski teoretičar Michele Cometa predložio je drugačiji pristup, a kojim se život slika nastoji sagledati ne iz suprotstavljenih pozicija ontologije i antropologije, nego iz promjenjive i, stoga, uvijek unaprijed neodredive, uloge slika u kulturalnoj povijesti čovječanstva. Cometa smatra da, zbog činjenice da smo suočeni s tako divergentnim pogledima na podrijetlo i mehanizme djelovanja slikovnog komuniciranja, moramo dopustiti da slike budu tumačene iz promjenjive perspektive koju bismo mogli nazvati oksimoronom - povijesna ontologija. Cometa postavlja četiri općenita pitanja o naravi slika, koja su osmišljena tako da onemoguće spoznavanje njihove jedinstvene suštine jer u takvoj vizuri slikovna bit zapravo i ne može postojati. Talijanski autor podjednako uzima u obzir uvide Beltinga, Freedberga i Mitchella, premda je ovaj potonji najbliži i Cometinom i našem tumačenju slika izvan ograničavajućih disciplinarnih kanona.

U članku pod naslovom » The Challenge of Cave Art: On the Future of Visual Culture«, Michele Cometa postavlja pitanja što, kada, kako i gdje je slika? ${ }^{13}$ Njegova povijesna relativizacija slikovne suštine vidljiva je već iz činjenice

Na drugačiji, ali opet vrlo sličan način, ovaj fenomen dvostruke prirode slike kao »stvarne nestvarnosti« opisao je i Gottfried Boehm u tekstu »Jenseits der Sprache? Anmerkungen zur Logik der Bilder«, u: Gottfried Boehm, Wie Bilder Sinn Erzeugen. Die Macht des Zeigens, Berlin University Press, Berlin 2007., str. 34-53; hrv. prijevod: G. Boehm, »S one strane jezika? Bilješke o logici slika«, prev. Martina Horvat, Europski glasnik 10 (2005), str. 459-469. Boehm govori o »višku smisla« koji slike proizvode u odnosu na stvarnost: »one su stvar i istodobno ne-stvar, nešto između aktualne stvarnosti i nematerijalnosti snova«. - Ibid., str. 37.

8

Luca Vargiu, »Luigi Russo e il 'quadrante metateorico' di Nicea«, u: Elisabetta Di Stefano, Salvatore Tedesco (ur.), La storia dell'estetica. Ricordando Luigi Russo, Aesthetica, Palermo 2020., str. 287-295.
9

David Freedberg, »Holy Images and Other Images«, u: Susan C. Scott (ur.), »The Art of Interpreting«, u: Papers in Art History from the Pennsylvania State University IX (1995), str. 68-70. Usp. H. Belting, Bild und Kult, str. 26-27, 517-526.

10

Ibid., str. 69, 71-72.

11

Vidi o tome u: Marie-José Mondzain, Image, Icon, Economy. The Byzantine Origins of the Contemporary Imaginary, Stanford University Press, Stanford 2004., str. 89.

12

L. Vargiu, »Luigi Russo e il 'quadrante metateorico’ di Nicea«, str. 290-292.

13

Michele Cometa, » The Challenge of Cave Art. On the Future of Visual Culture«, u: 
da on inače tipično »ontološka« pitanja postavlja u kontekstu paleolitskih vizualizacija, dakle, kao da je rani homo sapiens već posjedovao imaginacijski i naracijski potencijal postmodernoga čovjeka. Primjerice, premda paleolitski i suvremeni čovjek pripadaju istoj »spoznajnoj revoluciji $\ll,{ }^{14}$ pitanje što je slika (za svakoga od njih) ne može dati jedinstven odgovor, ali zato upućuje na interdisciplinarni i transhistorijski iskorak znanosti o slici utoliko što se ova koristi slikama pradavnog vremena da bi dala odgovore na probleme vlastitog. ${ }^{15} \mathrm{~S}$ jedne strane, proučavanje paleolitskih vizualizacija iz perspektive suvremene, zapadne vizualne kulture i humanistike - kao što su teorija pogleda i psihoanalitička teorija - danas proizvodi iznimno popularne kritike upućene širenju dominantnog diskursa Zapada i njegove primjene na kulture i narode kojima nikada nisu pripadali; s druge strane, i etablirani povijesno-umjetnički kanon već stoljećima operira s pojmovima stila i ekspresije da bi upisao vrijednosti u artefakte najstarijih vremena. Obje ove potrage za izvorištima, smatra Cometa, moraju nam omogućiti napustiti kako pojednostavljenja posthegelovskog historicizma, tako i uvjerenje prema kojemu su svi nedavni slikovni obrati - uglavnom promovirani razvojem medijskih tehnologija vizualizacije - potpuno originalni. ${ }^{16}$

Kada govori o tome kada je slika, Cometa se poziva na Horsta Bredekampa i na njegov pojam »slikovnog čina $\aleph^{17}$ prema kojemu se slika »pojavljuje« tamo gdje postoji čovjekova gesta koja će joj omogućiti da postoji, tj. da je na specifičan način učini živom. ${ }^{18}$ Talijanski autor skreće pozornost i na Mitchellovu »animističku« trijadu totemizam - fetišizam - idolatrija, što nam sugerira da su ljudi vlastitu želju za životom oduvijek projicirali na organski nežive predmete, poput fosilnih ostataka i kultnih slika: ${ }^{19}$ slika je, dakle, onda kada odlučimo da je želimo imati ispred sebe.

Kada postavlja pitanje kako je slika, Michele Cometa smatra da treba uzeti u obzir antropološke uvide (primjerice Hansa Beltinga i Randalla K. Whitea), koji smatraju da je tijelo prvi medij reprezentacije, jednako kao i one suvremenog »zaokreta prema materijalnosti«. Naime, slika se uvijek inkarnira u nekom mediju i zato je važno znati uspostaviti ispravnu vezu, mjesto susreta, između čovjeka kao osobe i čovjeka kao medija. Randall White nastojao je protumačiti materijalnu podlogu, predmete, kao proizvod kulturalnih reprezentacija, kao vanjske proteze čovjekove komunikacije s drugim ljudima. ${ }^{20}$ Spoznavanje važnosti materijalnosti slika neće nam samo objasniti odnos čovjeka i slikovne reprezentacije u doba "prirodnih medija« (stijena, stabala, čovjekove kože i tijela) nego ćemo pomoću nje moći i uspostaviti radikalne transhistorijske preskoke od pretpovijesti do suvremene kulture virtualnosti. Ono što je ranom homo sapiensu bio zid pećine, modernom čovjeku to su VR naočale - razlika je samo u vrsti medija, tj. materijalnoj osnovi kojom je raspolagao u određenoj fazi svojega razvoja.

Postavljajući pitanje o tome gdje je slika, Cometa se zalaže za afirmiranje tzv. »svjetske povijesti umjetnosti« koja bi trebala ukinuti europocentrizam zapadne tradicije i dominaciju zapadnih kulturnih paradigmi općenito. Također, ovakva nova znanost o umjetnosti oslobodila bi klasičnu povijest umjetnosti od njezine disciplinarne izolacije te uključila evolucijsku biologiju, neuropsihologiju i kognitivne znanosti. Konačno, ona bi stvorila mjesto za proučavanje slika unutar povijesti evolucije na taj način što bi ispreplela povijesnu dinamiku »stvaranja slika « s historiografskim »stvaranjem priča «. ${ }^{21}$ Naravno, interpretacijski kvadrat omeđen strateškim pitanjima što, kada, kako i gdje je 
slika može se približiti objektivnoj epistemološkoj analizi slika samo utoliko, ukoliko ne favoriziramo ili pak diskriminiramo bilo koje od njih.

Jedan od »klasičnih« povjesničara umjetnosti za kojega možemo ustvrditi da slijedi ne-klasične metode »povijesti umjetnosti kao povijesti slika« jest i onaj kojeg spominje Cometa - njemački teoretičar Horst Bredekamp. Vjerojatno nije slučajno da su Bredekampov programatski tekst, »A Neglected Tradition? Art History as Bildwissenschaft« iz 2003. godine, tada još malobrojni sljedbenici vizualnih studija i teorije slike mogli prvi puta pročitati u časopisu Critical Inquiry, čiji je glavni urednik bio upravo W. J. T. Mitchell. ${ }^{22}$ Ono na što Bredekamp podsjeća u tom tekstu jesu interdisciplinarni počeci povijesti (ili znanosti o) umjetnosti koja je u djelima Heinricha Wölfflina, Abyja Warburga, Hermanna Grimma, Jacoba Burchardta, Erwina Panofskog i drugih obećavala ne-doktrinarni pristup umjetničkim djelima. Zašto suvremena povijest umjetnosti nije slijedila taj put tema je za novi članak, no Bredekampova knjiga Theorie des Bildakts iz 2010. godine odličan je primjer korištenja povijesno-umjetničkog materijala u svrhu uspostavljanja nove slikovne epistemologije. ${ }^{23}$

Bredekampova teorija slikovnoga čina tek je manjim dijelom usporediva $\mathrm{s}$ ranije spomenutim tezama Davida Freedberga i Hansa Beltinga, zato što mogućnost "govora slike u prvom licu« kod ovog autora, više nego kod prve dvojice, odaje sposobnost slika za autentičnim djelovanjem, poput razgovora

Žarko Paić, Krešimir Purgar (ur.), Theorizing Images, Cambridge Scholars Publishing, Newcastle upon Tyne, str. 22-34.

14

Ibid., str. 23.

15

Ovdje treba napomenuti da Michele Cometa ne koristi pojam »znanost o slici«, nego »vizualna kultura«. O razlozima zašto bi, smatramo, u ovom slučaju trebalo koristiti prvi pojam te o razlikama među znanosti o slici, vizualnih studija i vizualne kulture pisali smo u knjizi: Krešimir Purgar, Iconologia e cultura visuale. W. J. T. Mitchell, storia e metodo dei visual studies, Carocci editore, Rim 2020., str. 52-55, str. 59 - bilj. 3 .

16

M. Cometa, »The Challenge of Cave Art «, str. 24

17

Horst Bredekamp, Theorie des Bildakts, Suhrkamp, Berlin 2010, vidi posebno str. 35.

18

M. Cometa, »The Challenge of Cave Art «, str. 25. U knjizi What Do Pictures Want?, W. J. T. Mitchell navodi sličan argument kada kaže da jedan isti objekt, primjerice zlatno tele, može imati funkciju, tj. biti doživljen $i$ kao totem $i$ kao fetiš $i$ kao idol, ovisno o društvenoj praksi i narativu koji ga okružuju: »Kada se na tele gleda kao na čudesnu Božju sliku, to je idol; kad se na njega gleda kao na samosvjesno proizvedenu sliku plemena ili nacije [...], to je totem; kada se naglasi njegova materijalnost i vidimo ga kao rastaljeni konglomerat privatnih predmeta, naušnica i zlatnog nakita koje su Izraelci donijeli iz Egipta, tada on postaje kolektivni fetiš.« - W. J. T. Mitchell, What Do Pictures Want?, str. 188-189.

19

Vidi o tome u: W. J. T. Mitchell, What Do Pictures Want?, str. 188-189; William John Thomas Mitchell, The Last Dinosaur Book, The University of Chicago Press, Chicago 2005.

20

M. Cometa, »The Challenge of Cave Art«, str. 28.

21

Ibid., str. 30.

22

Horst Bredekamp, »A Neglected Tradition? Art History as Bildwissenschaft«, Critical Inquiry 29 (2003) 3, str. 418-428, doi: https:// doi.org/10.2307/1344348.

23

Horst Bredekamp je prvo izdanje knjige iz 2010. naslovio Theorie des Bildakts, a zatim je u drugom izdanju iz 2015. izostavio pojam »teorije« iz naslova. Englesko izdanje, korišteno ovdje, objavljeno je 2018. pod naslovom Image Acts. A Systematic Approach to Visual Agency (prev. Elisabeth Clegg, Walter De Gruyter, Berlin - Boston). 
dvoje ljudi u kompleksnoj jezičnoj komunikaciji. Bredekamp o svojoj metodi kaže:

»Novi pristup locira sliku ne na mjestu koje je nekada zauzimala izgovorena riječ, već na mjestu koje je nekada zauzimao govornik. Ukratko, slika više nije instrument već dionik - zapravo je ona 'pokretač', glavni junak. Slikovni čin [...] usvaja dinamiku što postoji u odnosu između govornog čina i njegova vlastitog društvenog, političkog i kulturnog okruženja, ali polazište pronalazi u latentnoj sposobnosti slike da potakne gledatelja. $\ll^{24}$

»Vizualno djelovanje«, sintagma iz podnaslova engleskoga izdanja Bredekampove knjige, označava ne samo istraživanje učinka slika nego i učinke jedne nove, post-semiotičke i post-fenomenološke, u pravom smislu riječi post-moderne hibridne teorije slike, koja prisvaja i isprepliće uvide različitih disciplinarnih praksi i preoblikuje ih u otvoren teorijski narativ.

Bredekamp iscrpno elaborira tri tipa slikovnih činova:

1) Shematski slikovni čin odlikuje se, prije svega, neposrednim učinkom »života« svojstvenog slici; taj život dolazi do izražaja kada sliku doživljavamo kao da nam se obraća »u prvom licu jednine«, a najviše kada nam slika $u$ vlastito ime izdaje zapovijed $\mathrm{u}$ formi teksta napisanog na slici ili ugraviranog u skulpturi, kada je pretvorena $\mathrm{u}$ tableau vivant te kada je tehničkim ili vizualnim sredstvima stvarno ili metaforički pokrenuta.

2) Zamjenski slikovni čin karakterizira »razmjena slike i tijela«, kao što je to načinio Jan van Eyck u svom (kasnije izgubljenom) Portetu Krista, na kojem je napisao, u Isusovo ime: Joha[nn]es de eyck me fecit et amplevit anno 145831 Januarij. U zamjenskom slikovnom činu, kako to radikalno pokazuje van Eyckov Krist, Bredekamp će prepoznati simptomatsku karakteristiku vizualne reprezentacije, vjerojatno dijelom i na Beltingovom tragu, gdje je tijelo medij slike i obratno. ${ }^{25}$

3) Intrinzični slikovni čin Bredekamp prepoznaje u formalnim aspektima artefakata, njihovom izgledu koje su ljudi držali važnima tijekom cijele kulturalne povijesti, a ne samo tijekom ili unutar discipline povijesti umjetnosti. Pogotovo se to odnosi na radove u kojima se uočava izravna veza forme i trenutka kreacije, poput Tizianove Nimfe i Pastira iz 1575., Rembrandtova Olujnog pejzaža iz 1657., sve do Ikonoklastičke kontroverze Anselma Kiefera i akcijskog slikarstva Jacksona Pollocka u dvadesetom stoljeću. ${ }^{26}$

Bredekampova tri slikovna čina doimaju se osobito instruktivnima kao doprinos obnovi tradicije "povijesti umjetnosti kao znanosti o slici«, tj. kao realizacija jednog od mnoštva mogućih teorijskih modela unutar povijesno-umjetničkog nasljeđa. Tradicionalna disciplina povijesti umjetnosti je teorijom slikovnih činova izgubila svoja sigurna uporišta i sada sa svakim novim interpretacijskim modelom »igra« može početi iznova, poput karata koje se uvijek iznova miješaju na početku nove partije. U nastavku ćemo pokušati ustanoviti izglede za hermeneutiku slike u slučaju kada okviri analize postanu još širi, nego su to bili kod Freedberga, Beltinga, Comete i Bredekampa. 


\section{Ikonologija i kulturalna triangulacija: Mitchell i Panofsky}

Suvremena vizualna kultura, a djela suvremene umjetnosti pogotovo, otvaraju prostor različitim vrstama tumačenja, koja ovise o načinu na koji kontekstualiziramo vizualne artefakte, t j. tumačenja ovise o individualnim razlozima zašto ih uopće gledamo te što u njima želimo vidjeti, bez obzira činimo li to unutar povijesti umjetnosti ili slikovne epistemologije u širem smislu. Kada spominjemo »individualne razloge « gledanja, ne mislimo pritom na poststrukturalističke politike identiteta jer je problematika identiteta u vizualnoj kulturi samo-legitimirajuća. Drugim riječima, ona ne uzima u obzir ontološko utemeljenje slika, nego prvenstveno njihovo ideološko samo-opravdanje. Mi ovdje nastojimo uspostaviti širi okvir. Osim u rijetkim slučajevima, ljudi su slike oduvijek proizvodili kako bi one bile prijenosnici pragmatične komunikacije, ali to ne znači da funkcija slike nužno iscrpljuje sve njezine aspekte koji u nekom povijesnom trenutku mogu izbiti u prvi plan. Radikalno apstraktno slikarstvo Jacksona Pollocka, Franka Stelle, Barnetta Newmana i Julija Knifera jedan je od rijetkih slučajeva nepragmatične komunikacije. S druge strane, možda će se slike što danas nastaju frenetičnim snimanjem pomoću mobitela u bližoj budućnosti tumačiti kao specifična podvrsta apstrakcije zbog dominacije forme nad sadržajem, jednako kao što danas pokušavamo naći smisao u »crnim platnima« Ada Reinhardta, a čiji smisao više nije (samo) u opravdanju povijesno-umjetničke teleologije nego ga pronalazimo uvijek kada slike pridonose filozofskim, antropološkim, tehnologijskim ili nekim drugim uvidima.

Ukoliko, dakle, želimo definirati metodološki okvir interdisciplinarne analize slika, taj okvir mora biti utemeljen na nekim općim mjestima zajedničkim svim slikama, kako smo to uočili kod Davida Freedberga, Michelea Comete i Horsta Bredekampa. No, za razliku od »ontologije inherencije«, pitanja što, kada, kako i gdje je slika te »teorije slikovnih činova«, u nastavku ćemo predložiti još jedan model za koji smatramo da podjednako uzima u obzir povijesne, kulturalne i filozofske aspekte slika. Krenimo od pojmova koje W. J. T. Mitchell iznosi kao prikladan alat u srazu s proizvodima vizualne kulture koje smo ovdje nazvali »kulturalna triangulacija« - a to su: historizacija, dekontekstualizacija i anakronizacija. O njima je Mitchell govorio gotovo usput na simpoziju održanom 2011. godine u Chicagu, koji je nosio tako prozaičan, a ipak enigmatski naziv: »Što je slika?«. Tada je američki teoretičar predložio tri metodička postupka koja do temelja razaraju povijesno-umjetničko usta-

24

H. Bredekamp, Theorie des Bildakts, str. 33. 25

Belting o tome kaže: »Korištenje vizualnih medija igra središnju ulogu u razmjeni slike i tijela. Mediji tvore kariku koja nedostaje između jednih i drugih jer kanaliziraju našu percepciju i tako nas sprječavaju da ih ili zamijenimo za stvarna tijela ili za puke predmete ili strojeve. Naše vlastito tjelesno iskustvo omogućuje nam prepoznavanje dualizma svojstvenog vizualnim medijima. Znamo da svi mi imamo ili da svi posjedujemo slike, da one žive $u$ našim tijelima ili $\mathrm{u}$ našim snovima i čekaju da ih naša tijela pozovu da se pojave. Neki jezici, poput njemačkog, razlikuju pojam za pamćenje kao arhivu slika (Gedächtnis) od izraza za pamćenje kao aktivnost, odnosno kao naše prisjećanje na slike (Erinnerung). Ova razlika znači da i posjedujemo i stvaramo slike. U svakom slučaju, tijela (to jest mozak) služe kao živi medij koji nas tjera da opažamo, projiciramo ili pamtimo slike i koji također omogućuje našoj mašti da ih cenzurira ili transformira.« - Hans Belting, »Image, Medium, Body: A New Approach to Iconology«, Critical Inquiry 31 (2005) 2, str. 302-319, ovdje str. 305-306.

26

H. Bredekamp, Theorie des Bildakts, str. 57$58,75,224-230$. 
novljenje umjetničkog djela, ali koji istodobno uspostavljaju trans-disciplinarne kriterije nove znanosti o slici. ${ }^{27}$

Mitchell, naime, kaže da slike uvijek najprije treba staviti u njihov povijesni kontekst, no da se taj kontekst isto tako sastoji od »diskursa, jezika i riječi«. To znači da povijest nije samo vrijeme koje je prošlo te da od njega ne baštinimo samo povijesne artefakte, poput slika, skulptura i arhitekture, nego da je povijest dostupna samo kroz načine na koje o njoj razgovaramo - a to su diskurzivni sklopovi i njihove sastavnice nižeg reda: jezik i riječi. Dakle, ne postoji povijest kojoj bismo imali pristup nekontaminiran različitim oblicima refleksije o toj istoj povijesti; kada pokušavamo objasniti povijesne slike nužno se upuštamo u metadiskurzivne refleksije o stvarima koje nisu ono što o njima govorimo. Jednostavno rečeno, Rubensova Otmica Sabinjanki nije (isključivo) ono što je o toj slici u stanju reći ni njezin najbolji poznavatelj. Ambivalencija diskursa jest, dakle, prvi problem svake interpretacije.

Ali stvari za slike sada postaju još teže jer se slike (pogotovo one koje zovemo figurativnima ili narativnima) dijalektički odupiru jeziku. Ovo se čini nerazrješivom aporijom: ako slike možemo tumačiti samo pomoću odgovarajućega kritičkog diskursa - tj. pomoću sklopa jezičnih konstrukcija kojima uspostavljamo značenje, kako slika tako i samog diskursa - kako ćemo onda prihvatiti naizgled posve intuitivnu spoznaju da slike ne mogu biti svedene samo na ono što o njima govore najumniji među nama? Iz pozicije povijesti umjetnosti, Mitchellovo rješenje sigurno se doima eskapistički jer ovaj autor - posve ikonoklastički - predlaže dekontekstualizaciju, tj. razmatranje slika unutar različitih i često nepovezivih sustava kojima one ne pripadaju. To bi značilo da je ono što smo o umjetničkoj ili bilo kojoj drugoj slici u stanju reći, u spoznajnom i vrijednosnom smislu, na istoj razini kao i sama slika. Naime, ako slika ne može govoriti u vlastito ime na isti način kako to čini diskurs kao kompleks jezika i vrijednosnih stavova, onda svaki drugovrsni iskaz o slici - ostvaren pomoću jezika, tehnoloških naprava ili drugih slika - također doprinosi vizualnoj spoznaji. Ovaj je uvid važan za razumijevanje suvremenih konceptualnih umjetničkih praksi jer legitimira autonomnost vrijednosnog suda izvan pretpostavljene umjetničke intencionalnosti, čak izvan bilo koje poznate hermeneutičke konvencije.

Metoda anakronizacije svakako je najproblematičnija iz vizure tradicionalnih kunst-historičarskih pristupa; istodobno, ona je ugrađena u temelje svih novijih teorijskih praksi poput vizualnih studija, znanosti o slici ili opće teorije slike. Ovdje je riječ o tome da se slike promatra na takav način da njihova uloga u sadašnjosti biva objašnjena u sinkronitetu upravo vremena u kojemu o njima raspravljamo, a ne da njihov značaj proizlazi iz povijesne vrijednosti (ova potonja, kao što smo rekli, u Mitchellovoj kulturalnoj triangulaciji obuhvaćena je metodom historizacije). Jedno od pitanja koje anakronizacija uvijek postavlja pred teoretičare, ali i generalnu publiku, jest je li nam, da navedemo samo jedan primjer, Caravaggiov stil chiaroscura važniji zbog uvida u opći povijesni razvoj slikarskog umijeća i uloge pojedinih umjetnika u tom razvoju na jednoj strani ili nas više zanima da uspostavimo veze u nepreglednoj širini ljudskog znanja, kojega je Caravaggio samo jedan dio, na drugoj strani. Metoda anakronizacije, naime, ne isključuje mogućnost udivljenja pred umjetničkim djelom, nego proširuje razloge tog udivljenja: prema tom pristupu, a u kombinaciji s ostala dva, udivljenje može nastupiti stoljećima kasnije te zbog posve različitih motiva. 
Kada bismo važnost umjetničkih djela procjenjivali isključivo na temelju njihove vrijednosti unutar povijesne epistemologije, tada bismo bili uskraćeni za mogućnost da umjetničko djelo skrene pozornost na sebe uvijek iznova, tj. da svakome govori ono što je on ili ona u njemu u stanju prepoznati iz perspektive vlastitih interesa i trenutka u kojemu ga promatra. No, znači li to da time umjetničkim djelima oduzimamo auru neponovljivosti i sublimne snage ili, još gore, da zastupamo stav prema kojemu za razumijevanje umjetnosti više nije potrebno nikakvo specifično znanje ili senzibilitet? Upravo suprotno: sposobnošću da umjetničko djelo ili bilo koji vizualni artefakt procjenjujemo iz »anakronističke« perspektive, tj. da ona bude metoda ili kriterij umjetničke prosudbe, uspostavlja se razlika između znanja kao connoisseurshipa i znanja kao kritičke prosudbene snage.

Prigovor koji se ovoj metodi može uputiti jest taj da je ona, za razliku od staklenog zvona connoisseurshipa, znatno više podložna ideologizaciji i korištenju umjetnosti u svrhu političkog ili vjerskog oportuniteta. Međutim, ni Kantova »moć suđenja« ne vodi nužno oslobođenju umjetnosti nakon što je nestalo njezine kultne funkcije, kako je to u povijesnoj perspektivi pokazao Hans Belting, ${ }^{28}$ nego se svevremenska »moć slike«, kako ju je razumijevao Freedberg, sada koristi protiv umjetnosti, unatoč tomu što slike nisu bile u pravom smislu riječi žive ni u jednoj od svojih povijesnih inkarnacija - još od biblijske Božje kazne Izraelcima zbog klanjanja zlatnom teletu, preko dogmi Drugog nicejskog sabora iz 8 . stoljeća, sve do protureformacijskih odluka Tridentskog koncila iz 16. stoljeća. Slučaj uništavanja modernističke umjetnosti, tzv. »entartete Kunsta« u Njemačkoj tridesetih godina 20. stoljeća, rušenje budističkih spomenika u afganistanskoj dolini Bamyan 2001. godine ili teroristički napad na redakciju časopisa Charlie Hebdo u Parizu 2015. godine na radikalan način svjedoče o opasnostima koje donosi beskrupulozna primjena anakronističke vizure umjetničkih djela, tj. posljedice koje nastupaju kada zanemarimo dimenzije povijesti i pozitivističke kontekstualizacije.

Premda su spomenute tri epizode zabilježene kao vjerojatno najspektakularniji dokazi snage slike - što ih je u novijoj povijesti učinilo najpoznatijim primjerima ikonoklazma, tj. zazora od slika - civilizirani prijepori posebno dolaze do izražaja u suvremeno doba, kada se odvijaju na razini disciplinarnih epistemologija, dakle, daleko od radikalnih iskaza vjere i ideološke čistoće. W. J. T. Mitchell u svojim je mnogobrojnim radovima uvijek bio posve svjestan da »supermarket slika« donosi sa sobom mnogo veću odgovornost teorije, tj. onih koji su profesionalno zaduženi da slikovne aporije razrješavaju na

27

Vidi o tome u: James Elkins, Maja Naef (ur.), What is an Image?, Penn State University Press, University Park 2011., str. 40.

28

U kontekstu teorije Hansa Beltinga, posebno je zanimljivo uspostaviti kontinuitet između njegovih dviju knjiga - prvog izdanja Das Ende der Kunstgeschichte? (Deutscher Kunstverlag, München) iz 1983., zatim Bild und Kult iz 1990. te drugog izdanja Das Ende der Kunstgeschichte. Eine Revision nach Zehn Jahren iz 1995. Naime, drugo izdanje knjige o kraju povijesti umjetnosti više nema upitnik u naslovu, iz čega zaključujemo da se Beltingova provokacija iz ranijeg naslova pretvorila u etabliranu znanstvenu figuru. Između ova dva izdanja Belting objavljuje Bild und Kult, svoju najpoznatiju knjigu, u kojoj on slike s kultnom funkcijom, nastale »prije doba umjetnosti«, dakle, prije rađanja građanskog društva, izuzima iz jurisdikcije povijesti umjetnosti. Simptomatično je da jedan od najvećih svjetskih povjesničara umjetnosti druge polovice 20. stoljeća tijekom velikog dijela svoje karijere sustavno dovodi u pitanje disciplinarne dogme vlastite struke te istodobno biva njezinim znamenitim predstavnikom. 
mjestima intelektualnog, a ne fizičkog sukoba. Jedan od njegovih najnovijih napora u tom smjeru bio je prvi puta objavljen u prvom broju časopisa Nove teorije 2019. godine, a odnosi se na potrebu da opća znanost o slikama - koju on naziva ikonologijom - u vlastite analitičke postupke kontinuirano unosi korekcije u skladu sa zastarijevanjem slika. To zastarijevanje naročito je ubrzano razvojem tehnologije, prvenstveno dosezima biokibernetičkih znanosti. Mitchell navodi tri stadija ikonologije, koje imenuje kao da je riječ o inoviranim inačicama računalnog softvera, uzimajući u obzir ne toliko stanje samoga »softvera«, koliko promjenu društvenih i tehnoloških okolnosti, što treba biti odraženo u kompetencijama znanosti prilagođenima za susret s novim vrstama i učincima slika. Mitchell kaže:

»Prvi stadij - ikonologija 1.0 - omogućen je izumom fotografije i sastavljanjem globalnoga kros-kulturalnog atlasa slika. Atlas Mnemosyne Abyja Warburga bio je najistaknutiji simptom ovog pokušaja totalizacije svijeta slika. Izgledao je poput oživljene drevne ikonologije, metode koju je Erwin Panofsky nastojao pretvoriti u disciplinu koja će tumačiti slike tako što će slijediti njihova značenja u različitim medijima. [...]

Ikonologija 2.0 nastupa onda kada su se informatička znanost i digitalno-analogna dijalektika spojili sa znanostima o životu (life sciences), a prve 'žive slike' počele su se pojavljivati kao uočljivo obilježje i popularne kulture i znanstvenih laboratorija. Benjaminovu mehaničku reprodukciju istisnula je ne digitalna već biokibernetička sinteza, koja je omogućila kloniranje. tj. reprodukciju živih slika živih bića - ono što bismo mogli nazvati 'bioslike'.

Ikonologija 3.0 jest tamo gdje smo sada, i poput svih ostalih koji pokušavaju svoj povijesni trenutak ispuniti osjećajem kritičke jasnoće, i ja sam uhvaćen u vrtlogu proturječnosti. To je djelomično zato što 3.0 ne stvara jasan rez prema prošlosti, već skuplja sve fosilne ostatke prethodnih vremena i ponovno ih animira u odnosu na naše vlastite okolnosti. $\ll^{29}$

U svome tekstu, Mitchell ne navodi specifične metode kojima se ikonologija služi ili se služila u svojim različitim razvojnim stadijima. Mi smo pisali o načinu na koji on sam uspostavlja ikonologiju kao »kulturalnu simptomatologiju«, kao cijeli niz ad-hoc konstruiranih narativa oko ključnih tema. ${ }^{30} \mathrm{U}$ tome se njegova metoda značajno razlikuje od one Panofskog, primjerice, jer je njemački autor inicijalno zamislio da svako umjetničko djelo bude podvrgnuto istom skupu metodoloških postupaka: prirodni, konvencionalni i intrinzični aspekt djela pretpostavljaju kod Panofskog da svako djelo već unaprijed posjeduje ta svojstva te ih adekvatnom analizom samo treba rasvijetliti. Kod Mitchella se svojstva slika uspostavljaju kroz prepoznavanje u njima kulturalnih simptoma različitih epoha, a koje simptome, upravo zbog neizvjesnog rezultata metode koju bismo mogli nazvati $\mathrm{i} »$ kros-kulturalnom triangulacijom«, nije moguće unaprijed uspostaviti. Prema tom modelu, svakim novim činom rasprave o umjetničkom djelu ili bilo kojoj slici interpretacija započinje iznova: potrebno je uspostaviti kriterije koji su prilagođeni upravo onome što se tumači kako bi se u dotičnom djelu otkrili njegovi ključni simptomi kao funkcije svojstava vremena u kojemu je ono nastalo, okolnosti unutar kojih se tumači i specifičnog interesa onoga tko iznosi svoj sud.

Da bismo metodološki ostali u okvirima koje su predložili Panofsky tridesetih godina, a Mitchell devedestih godina 20. stoljeća, poslužit ćemo se ikonologijom kao općom znanošću o slici. Krenimo s prvom od tri razine koje predlaže Panofsky: na »prirodnoj« razini prepoznajemo da se radi o slikama u širokom rasponu od figuracije do djelomične ili potpune apstrakcije uz često korištenje tekstualnih iskaza, a čije je značenje koji puta izravno povezivo s prikazom a koji puta nije. »Konvencionalni« ili ikonografski aspekt govori nam da je riječ o hermeneutičkom postupku koji se može jednako referirati na historijske aspekte neke kulture, poput povijesnih događaja, na simboličke aspekte kao 
što su tekstovi iz Novog zavjeta, ali i na dionice značajne za razvoj moderne i suvremene umjetnosti. Kada je riječ o potonjemu, u završnom poglavlju ovoga teksta nastojat ćemo potvrditi našu teoriju aproprijacije na taj način što ćemo skrenuti pozornost na slike Zlatka Kozine čije razumijevanje nije moguće bez uočavanja referenci na Josepha Kosutha, Bracu Dimitrijevića, Eda Ruschu, Marinu Abramović, na teorijske postavke Clementa Greenberga, suvremeno art-izdavaštvo i teme povezane s lokalnom, hrvatskom umjetničkom scenom. Na »intrinzičnoj« ili ikonološkoj razini u užem smislu, dakle, onoj koju Panofsky smatra ključnom za određivanje značenja umjetničkog djela, radovi Zlatka Kozine, uz pomoć pojma aproprijacije, vodit će nas prema zaključku da je njihova ikonološka, tj. esencijalna vrijednost kao umjetničkih djela, upravo $u$ ispreplitanju različitih načina prisvajanja povijesno-umjetničkih stratuma, prvenstveno onih koji se odnose na modernu i suvremenu umjetnost. ${ }^{31}$

Ako bismo sada Mitchellovu verziju ikonologije kao kulturalne simptomatologije odlučili primijeniti na povijest umjetnosti, tada bismo pošli od onoga što smo, slijedeći metodu Panofskog, definirali kao treći stadij analize, to jest aproprijaciju ili prisvajanje vidljivih umjetničkih, kulturalnih i društvenih silnica koje ćemo u slikama Zlatka Kozine prepoznati kao njihovo bitno značenje. Međutim, razlika spram metode Panofskog je u tome što bi u dosljedno provedenoj mitchellovskoj analizi aproprijacija bila tek početak - a ne kraj - razmatranja značenja ovih slika; prisvajanje u tom slučaju postaje ona simptomatska osobina umjetničkog djela koju tek treba historizirati, dekontekstualizirati i anakronizirati. Dakle, osobit amalgam teorijskih uvida, ironičnih komentara i referenci dvadesetog i dvadesetprvog stoljeća prisutan (i) kod Kozine, uz Panofskog bi se vjerojatno tumačio na aksiološkoj, tj. vrijednosnoj razini, dok bi primjenom Mitchellove teorije bila riječ o simptomatskoj razini, to jest o osobinama stanja ili vremena u kojemu izričemo svoj sud te o posljedicama koje naš sud ima na eventualno promijenjeni status slike ili umjetničkog djela.

Ako strategiju prisvajanja prihvatimo kao jedan od simptoma našega vremena, ambicioznija kritičko-teorijska refleksija neće se zaustaviti na toj naizgled jednostavnoj premisi, nego će dekontekstualizirati logiku prisvajanja našega vremena usporedbom s načelima aproprijacije u nekom drugom vremenu, da bi se uspostavio Mitchellu toliko bitan povijesni preskok između historizacije i anakronizacije. Bez namjere da ovaj osvrt iscrpi sve potencijalne kontekstualne izvore (to ionako nikada nije moguće), u nastavku ćemo preliminarno prikazati jedan mogući model povijesne tipologije aproprijacije, a koji zaslužuje da se njime posebno bavimo na drugome mjestu.

William John Thomas Mitchell, »Iconology 3.0 - Image Theory in our Time«, New Theories / Nove teorije (2019), br. 1, str. 25-27. Dostupno na: http://www.uaos.unios.hr/casopis-new-theories-nove-teorije/ (pristupljeno 15. 4. 2021.).

30

Vidi o tome u: K. Purgar, »Iconology as Cultural Symptomatology«, str. 82-99.
31

O teoriji Panofskog vidi u Erwin Panofsky, Meaning in the Visual Arts. Papers in and on Art History, Anchor Books, New York 1955. str. 28-31. 


\section{Nacrt tipologije aproprijacije u vizualnim umjetnostima}

Pojam prisvajanje postao je kolokvijalan u teoriji umjetnosti u trenutku kada smo unutar zapadne kulture počeli primjećivati uspostavljanje tzv. "postmodernističke« paradigme, a koju u vizualnim umjetnostima najčešće tumačimo kao napuštanje modernističke težnje k originalnosti. Simptomatično je da ovaj postmodernistički zaokret teorijski najbolje opisuju knjige teoretičara arhitekture, Charlesa Jencksa i Lionella Venturija, ${ }^{32}$ koje su nam razotkrile da su i modernističke inovacije u vizualnoj kulturi Zapada (nastale početkom 20. stoljeća) velikim dijelom utemeljene upravo u prisvajanju formalno-stilskih - nipošto epistemoloških ili kultnih - osobina slikovne produkcije iz različitih epoha brojnih svjetskih kultura. S izuzetkom relativno kratkotrajne ranomodernističke vjere u mogućnost stvaranja slikovne spoznaje iz unutarnjeg prostora čovjekova duha ili osjetilnosti (kao u Vasilija Kandinskog i Kazimira Maljeviča), a koja je potom kulminirala u visokomodernističkom pokušaju stvaranja savršene ili apsolutne slike (kao u Ada Reinhardta i Julija Knifera), kulturalna povijest čovječanstva u svojoj je suštini povijest palimpsesta, citata, pastiša, preuzimanja i prisvajanja. Četiri faze u povijesti aproprijacije u vizualnim umjetnostima koje ovdje predlažemo možemo, stoga, promatrati na teorijskom tragu ranije spomenute Bredekampove povijesti umjetnosti kao »zanemarene tradicije«, a koja upravo sada doživljava svoju »postmodernu« fazu.

Aproprijacija 1.0 nastupa u razdoblju renesanse, kada se vraća interes za antičku estetiku i filozofiju. Premda je umnogome riječ o prisvajanju koje zapravo ne preinačuje u značajnoj mjeri antički izvornik, barem kada je riječ o stilskim elementima, zbog velikog vremenskog raspona od gotovo tisuću godina, mislim da bismo vizualnu kulturu renesanse mogli nazvati prvim primjerom prisvajanja od općega kulturno-povijesnog značaja. Neoklasicizam, koji se javlja u drugoj polovici osamnaestog stoljeća, dio je tog antikizirajućeg procesa u zapadnoj kulturi koji je trajao dva milenija. Prvoj je aproprijaciji legitimitet dala upravo disciplina povijesti umjetnosti jer je ona sama nastala velikim dijelom iz potrebe rekonstrukcije »aristotelovske linije«, a koja je tijekom mnogih stoljeća presudno utjecala kako na formalno oblikovanje umjetničkih djela (dakako, riječ je o načelu mimezisa), tako i na metodološke postupke povijesti umjetnosti, među kojima su ikonografija i formalna analiza među notornim primjerima. Ovo teorijsko utemeljenje poetike prisvajanja, smješteno u samoj srži povijesno-umjetničkog etosa, paradoksalno je označilo početak kraja povijesti umjetnosti jer ova disciplina nikada nije uzela u obzir da se prisvajati mogu najrazličitiji aspekti kulture, a ne samo specifični objekti za koje se traži da nužno moraju posjedovati povijesno-umjetničku verifikaciju.

Aproprijaciju 2.0 možemo zamijetiti početkom dvadesetog stoljeća, kada se interes europske moderne umjetnosti okreće prema stilemima nadahnutima vizualnom kulturom »egzotičnih« krajeva: Afrike, Oceanije i pretkolumbovske Amerike. Premda je iz perspektive radikalne političke korektnosti našeg vremena povijesna avangarda barem jednim dijelom nastala na geopolitičkom projektu kolonijalizma - dakle, na neprihvatljivim premisama eksploatacije kulturnog nasljeđa koje su umjetnici Zapada koristili samo kako bi se oslobodili oponašanja prirode - danas ipak znamo da je ta, druga aproprijacija, bila samo jedan od načina da se promijeni dvomilenijska aristotelovska paradigma. O epohi nakon mimezisa govori, među ostalima, knjiga La linea analica dell'arte moderna talijanskog teoretičara umjetnosti Filiberta Menne u 
kojoj ovaj autor obrazlaže da je jedan pol razvoja avangardne umjetnosti išao smjerom »fare l'arte« (stvarati umjetnost), a drugi »fare il discorso sull'arte« (stvarati govor o umjetnosti). ${ }^{33}$ Menna pritom ne misli na razdjelnicu koja modernu umjetnost dijeli na umjetničku praksu, s jedne strane, i kritičko-teorijske analize, s druge. Ovdje je riječ o tome da sami umjetnici kroz vlastite radove počinju postavljati teorijski intonirana pitanja o ontološkoj problematici umjetnosti kao kategoriji ili vrsti spoznajne i društvene aktivnosti.

Menna je svoju originalnu teorijsku analizu moderne umjetnosti uspostavio pomoću klasične semiotičke aporije koja je u vijeme kada je pisao knjigu bila vrlo popularna: naime, analitička linija o kojoj govori dijeli se na figure, tj. objekte koji ne denotiraju konkretno značenje i icone, djela koja omogućavaju kompleksne jezične iskaze. ${ }^{34}$ Međutim, kod ovog autora figure nisu figurativna, nego apstraktna djela, niti su icone ona umjetnička djela koja se referiraju na izvanslikovnu stvarnost, već isključivo na same sebe - to su ready-made objekti i konceptualna umjetnost, poput Duchampove Fontane iz 1917. i instalacije Josepha Kosutha Jedna i tri stolice iz 1965. godine. Znakovito je da Filiberto Menna u svoje dvije analitičke linije moderne umjetnosti nije uvrstio ono što ovdje zovemo ranomodernističkom aproprijacijom 2.0. Za nju bi trebalo formirati treću, paralelnu liniju koja bi obuhvaćala upravo poveznice između, primjerice, ekspresionizma i vizualne kulture otoka Palau ili kubizma i animističke tradicije crne Afrike.

Aproprijacija 3.0 nastupa s postmodernističkim prisvajanjem svih oblika vizualno-kulturalnih praksi - filma, arhitekture, književnosti, stripa, industrije zabave i sl. - te njihovim uključivanjem u tržišno-galerijsku matricu kasnog kapitalizma. Prvi postmodernistički vizualni umjetnik - Andy Warhol - najpoznatiji je i najkarakterističniji primjer zaokreta u umjetnosti do kojeg je došlo napuštanjem visokomodernističkog sna o društvenoj utopiji, s jedne strane, i potrebe za »monetizacijom« simboličkog kapitala (tj. umjetnosti), s druge. Iz naše današnje vizure, čini se da fenomen treće aproprijacije, za razliku od prve i druge, nema vijek trajanja i da je ona postala naturalizirani oblik razmjene kulturnih i novčanih dobara, čak u tolikoj mjeri da se razlika između umjetnosti i novca posve izgubila.

Najnoviji oblik prisvajanja, aproprijacija 4.0, daje naslutiti da je načelo radikalne permisivnosti postmodernog doba uspješno prešlo u svoju završnu, »baroknu fazu« ${ }^{35}$ naime, sveprisutnost slika i kulturalnih referenci, razmje-

32

Vidi o tome $\mathrm{u}$ temeljnim djelima postmoderne teorije arhitekture i vizualnih umjetnosti: Charles Jencks, The Language of Post-Modern Architecture, Rizzoli, New York 1977.; Lionello Venturi, Learning from Las Vegas, The MIT Press, Massachusetts (MA) 1972.

33

Filiberto Menna, La linea analitica dell'arte moderna: le figure e le icone, Giulio Einaudi, Torino 1975., str. 20.

34

Ibid., str. 65 .

35

Okosnica pojma neobarok, kao i glavna tema knjige L'età neobarocca talijanskog semiologa Omara Calabresea iz 1987. godine temeljila se na ideji da se društva razvijaju i mijenjaju tijekom stoljeća potaknuta stalnim porivom da prijeđu samonametnute granice znanstvenih i umjetničkih dostignuća. Oslanjajući se na koncept semiosfere Jurija Lotmana, Calabrese tvrdi da svaki kulturni sustav u nekom trenutku svojega povijesnog razvoja počinje prelaziti granice koje su ranije činile okvir njegove egzistencije. Po toj teoriji, razdoblja stabilizacije umjetničkih i kulturnih kanona unutar bilo kojeg društva možemo nazvati klasičnima, dok poremećaje i pokušaje propitivanja postojećih pravila možemo nazvati baroknima. - Omar Calabrese, L'età neobarocca, Laterza, Bari 1987. 
na banalnosti na društvenim mrežama i nova ideologija tehničke racionalnosti događaju se u trenutku kada su umjetničke vrijednosti napustile domenu »prosvijećene« ekonomske i intelektualne elite - što je, pored stilskih persiflaža, citatnosti i pastiša, bila najvažnija društvena karakteristika stadija Aproprijacije 3.0 - i počele su ploviti nepreglednim prostranstvima mreže. To ih je učinilo dijelom intelektualnog imaginarija daleko većeg broja ljudi, koji zahvaljujući internetu imaju nadohvat ruke kompleksne radove i još kompleksnije teorijske eksplikacije; dok, s druge strane, modernistička borba za snagom individualnog uma u sveprisutnoj mrežnoj komunikaciji skončava u trivijalizaciji. Ovdje želimo skrenuti pozornost na načelo prisvajanja kao strategije koju, kako smo vidjeli, podjednako koriste umjetnici, teoretičari i globalni kapital. S druge strane, uvide Filiberta Menne naveli smo kao primjer da je povijest moderne umjetnosti moguće promatrati i iz »romantičarske« perspektive radikalne originalnosti koja se danas čini nemogućom, jednako kao što se čini nemogućim svijet u kojemu je spoznaja originalnosti još uvijek imala nekakav smisao i društvenu vrijednost.

U dosadašnjem dijelu izlaganja nastojali smo pokazati da razumijevanje umjetničkih djela, jednako kao i svih drugih slika, ovisi o dvosmjernom procesu: inicijalno, ljudi su stvarali slike kako bi u njima vidjeli ono što u njima žele vidjeti, a tijekom kulturalno-povijesne sedimentacije različitih razina označavanja prvobitne namjere nužno izlaze iz imaginarija vremena u kojemu su nastale te vrše pritisak na novouspostavljene sustave tumačenja u epohama koje se bitno razlikuju od razdoblja u kojemu je djelo nastalo. Razlikuju se ne samo formalno-stilski, što je u fokusu povijesti umjetnosti, nego i svrhom, ulogom i društvenom funkcijom, a čime se bave mnoge druge discipline. Premda će intelektualna elita uvijek imati predilekcije prema umjetnosti koja slijedi ideološko-politički oportunitet trenutka, jedna je od najvažnijih funkcija tumačenja umjetnosti oduvijek bila razotkrivanje dinamike ljudske interakcije $u$ domeni spoznaje, a ne angažiranje umjetnosti za konkretne ciljeve (ovdje namjerno ne uzimamo u obzir ciljeve samih umjetnika).

Na slikama Zlatka Kozine - a pogotovo kada ih vidimo u gustom galerijskom izložbenom rasporedu - koegzistiraju teorije Clementa Greenberga i W. J. T. Mitchella, ironija na hiperprodukciju tzv. art-izdavaštva, osobni komentari na umjetnike koje je volio ili možda nije, prokazivanje uloge kustosa kao medijskih zvijezda, polu-božanstava ili pak mučenika, trajni sukob apstrakcije i figuracije, uz relativizaciju svega onoga što je Arthur Danto nazvao »svijetom umjetnosti« - univerzuma u kojemu je umjetnost dio začudnog spektakla novca, taština i, samo ponekad, genijalnosti. Radovi Zlatka Kozine, kao i koncept Aproprijacije 4.0, razotkrivaju mehanizam funkcioniranja društva u aktualnom vremenu razmjenjivosti svih intelektualnih vrijednosti i istodobno upućuju na status umjetnosti u doba apsolutne vladavine kapitala. No, postavlja se pitanje o tome u kojoj su mjeri intelektualne vrijednosti prenosive iz jedne razine spoznaje u drugu, tj. ako je simboličko prevrednovanje popularne kulture i njezino pretvaranje $u$ visoku umjetnost još imalo spoznajnu relevantnost u pop-artu, kakav se učinak proizvodi kada primijenimo suprotan proces: onda kada se intelektualne vrijednosti što ih nalazimo u nekim umjetničkim djelima, ili pak vizualna kultura općenito, koriste kao rasuti komadići znanja koje je potrebno ponovo spojiti u novu, možda i originalnu cjelinu?

Zlatko Kozina daje naslutiti da je proces rekonstrukcije znanja u doba Wikipedije mnogo kompleksniji od posmodernističke dekonstrukcije medija, kulture, autora, značenja i jezika. Njegovi radovi ispituju mogućnost epistemo- 
logije umjetnosti u dvostrukom, analitičkom i sintetičkom modelu. Kada je riječ o prvome, Kozina kao da postavlja pitanje o tome koliko elementarnog znanja moramo posjedovati o umjetničkoj slici da bismo doista mogli tvrditi da je razumijemo, a kada je riječ o potonjem, kako povezati sliku i tekst izvan uobičajene podjele funkcija prema kojoj slika pokazuje nešto, a tekst govori o nečemu. Kroz jednostavnu estetiku art bruta, ove su slike duboko subverzivne jer suočavaju promatrača s fragmentima njegova/njezina vlastitog (ne) znanja o vizualnoj konstruiranosti kulture te o životu kao spektaklu u doba totalne komunikacije. Utoliko aproprijacija 4.0 ne znači samo pridruživanje najšireg polja popularne kulture sferi visoke umjetnosti nego, još značajnije i - paradoksalno - još originalnije, znači prisvajanje posvećenih fragmenata svijeta umjetnosti i teorije te njihovo pretvaranje u prazne relikvije vizualne kulture.

Umjetničku vrijednost slika Zlatka Kozine, koje karakteriziraju neupadljivi formati i nespecifična slikarska tehnika, treba tražiti upravo u vizualizaciji krajnje ne-intuitivnog, "post-postmodernog« reverzibilnog procesa slikovne epistemologije koja promatraču nudi samo onu razinu spoznaje koja je ekvivalentna njegovoj vlastitoj inicijativi u spoznajnom procesu. To je slikarska strategija koja funkcionira poput umjetničkog esperanta, univerzalnog jezika bez nacije i teritorija sastavljenog od komadića naše kolektivne memorije. Aproprijacija 4.0 u ovim slikama nadaje se kao intelektualna aktivnost koja uključuje sve prethodne razine kulturalnog prisvajanja i na taj način Kozina opisuje kako funkcionira načelo izbora, sveprisutnosti i instantne dostupnosti svih informacija u našem aktualnom vremenu.

\section{Zaključak}

Ukoliko, na kraju, odlučimo odgovoriti na pitanje iz naslova »što slike znaju? «, poučeni prezentiranim teorijskim uvidima te neposrednim iskustvom promatranja, odgovor može biti samo krajnje relativan: slike znaju isto ono što znaju i ljudi koji ih gledaju - mnogo, malo ili ništa. Premda su se njihovi praktični režimi mijenjali tijekom cjelokupne kulturalne povijesti slika, držimo da su upravo tisućljetna strategija prisvajanja, preuzimanja i sedimentacije slikovnog značenja pridonijela razvoju svojevrsne dvostruke epistemologije - onoga što čovjek zna o slikama koje promatra, kao i onoga što je na slikama upamćeno o čovjekovom odnosu prema slikama. No, možemo li memoriju slika smatrati njihovim vlastitim znanjem ili su one samo neživi medij, nešto poput spremnika kolektivne memorije? Ovo je pitanje više od retoričke figure jer, bez obzira na to što slike ne posjeduju biološke osobine života, reakcije koje ljudi imaju kada stoje ispred slika u muzeju, dok gledaju obiteljske fotografije ili film u kinu - smijeh, bijes, žalost, udivljenje ili ravnodušnost - upravo su one reakcije koje očekujemo u svakodnevnoj komunikaciji među ljudima.

Bredekampova teorija slikovnih činova, jednako kao i Mitchellove slike kao "žudeći objekti« te Beltingovo razmatranje ljudskog tijela kao »medija slike» upućuju na to da je interakcija čovjeka i slike ogledalo njegove vlastite želje za proizvodnjom paralelnog svijeta koji on doživljava stvarnim, ali, kako je to objasnio Lambert Wiesing, ne mora u njemu sudjelovati jer slika omogućava različite oblike participacije ili izostanka iz participacije u stvarnom događaju. ${ }^{36}$ Ono što slike »znaju« jest specifična posljedica činjenice da neživi objekti mogu posjedovati pamćenje, ali - za razliku od umjetne inteligencije - svoje znanje mogu aktivirati samo u recipročnom komunikacijskom odnosu 
s čovjekom. Kada bi taj odnos uključivao samo promatranje i tumačenje slika od strane čovjeka, kao što nam to predlaže tradicionalna povijest umjetnosti ili neke druge disciplinarne metode hermeneutike slike, tada bi ovdje predložena teorija aproprijacije bila samo jedan od mnoštva metodoloških alata humanističkih znanosti.

Zahvaljujući uvidima teoretičara i umjetnika o kojima smo govorili u ovom tekstu, mogli bismo zaključiti da slike ne odražavaju ni prirodni okoliš, ni čovjekova unutrašnja stanja, a nisu ni posljedica strojne inteligencije, dakle, uma koji je izvan čovjeka. One su poseban sustav imaginiranja koji nam, posve paradoksalno, pomaže da još uvijek budemo svjesni našega fizičkog svijeta. Zato slike ne znaju ništa više, ali ni manje od nas samih. Pojam aproprijacije nam je pomogao da bolje razumijemo mehanizme povijesnog sedimentiranja znanja u slikama, a kulturalna triangulacija trebala bi nam pokazati što treba poduzeti kako bismo do tog znanja doprijeli.

\title{
Krešimir Purgar
}

\section{What Do Pictures Know?}

\section{Art, Appropriation, Cultural Triangulation}

\begin{abstract}
In the paper, we try to elucidate the procedures that need to be applied if we want to establish the consequences that occur when the sediments of meaning in images are deposited on top of each other, creating a specific pictorial epistemology. We will point out some interdisciplinary mechanisms of image analysis, such as "cultural symptomatology" and "cultural triangulation", together with drawing a typology of cultural-historical sediments of pictorial meaning that we call appropriation. We conclude that Bredekamp's theory of image acts, as well as Mitchell's concept of pictures as "desiring objects" and Belting's consideration of the human body as "image media", suggest that the interaction between a human and an image is a mirror of human's own desire to produce a parallel world in which, as Lambert Wiesing explained, he or she does not have to participate. The image allows for different forms of participation or absence from participation in the event represented in the image. Therefore, what images "know" is a specific consequence of the fact that inanimate pictorial objects can possess memory but unlike artificial intelligence - can activate their knowledge only in a reciprocal communicative relationship with people.
\end{abstract}

\section{Keywords}

image, appropriation, cultural triangulation, image memory, William John Thomas Mitchell, Horst Bredekamp, Michele Cometa, David Freedberg losophy of Perception. Phenomenology and Image Theory; prev. Nancy Ann Roth, Blo- omsbury, London 2014. [Das Mich der Wahrnehmung. Eine Autopsie, Suhrkamp, Berlin 2009.], str. 132-154. 